\title{
L-Arginine Metabolism in Mitochondria Isolated From the Liver of Antarctic Fish Notothenia rossii and Notothenia neglecta
}

\author{
Edson Rodrigues ${ }^{1 *}$, Ana Cristina Miguez Teixeira Ribeiro ${ }^{2}$ and Metry Bacila ${ }^{2}$ \\ ${ }^{1}$ Departamento de Biologia; Universidade de Taubaté; edsonrod@unitau.br; São Paulo - SP - Brasil. ${ }^{2}$ Centro de \\ Ciências Biológicas e da Saúde; Pontifícia Universidade Católica do Paraná; Curitiba - PR - Brasil
}

\begin{abstract}
The arginase tissue distribution, the biochemical properties of the argininolytic system and the subcellular localization of the enzymes carbamoylphosphate synthetase, ornithinecarbamoyl transferase, glutamine synthetase and arginase in Antarctic fish, $\underline{N}$. neglecta and $\underline{N}$. rossii were the main aims of the present work. The tissue with highest argininolytic activity was the kidney distal portion amounting as much as four times the specific activity of the hepatic tissue. Arginase and ornithine carbamoyltransferase were found as mitochondrial enzymes, while glutamine synthetase and carbamoylphosphate synthetase were found as cytosolic enzymes. Argininolytic assays with isolated mitochondria gave values of $K_{\text {mapp }}$ for the hydrolysis of arginine 2 to 3.5 times higher than the values found for the $K_{m}$ with mitochondrial extracts. The effect of $\mathrm{Mn}^{2+}$ on the argininolytic activity displayed by isolated mitochondria and mitochondrial extracts, in reaction conditions near the physiological ones showed that membranes were fundamentally involved in the control of L-arginine metabolism.
\end{abstract}

Key Words: Antarctic fish, arginine, arginase, urea cycle, N. neglecta, N. rossii

\section{INTRODUCTION}

The L-arginine metabolism is closely related to the ureogenic activity in animals and excretion of urea, probably a prerequisite for the life in terrestrial environments, which display intermittent disposability of water (Hird, 1986; Mommsen and Walsh, 1989). The maintenance of cellular L-arginine levels is also essencial as precursor for the synthesis of proteins, polyamines, creatine, proline, glutamate and nitric oxide (Wu and Morris, 1998). Thus, the biological membranes have a central role in L-arginine subcellular distribution. Yeast cells have high capacity to concentrate L-arginine in vacuolar structure. The transport at the vacuolar membranes in Neurospora crassa and Saccharomyces cerevisiae is ATP dependent on $\mathrm{K}_{\mathrm{m}}$ values of $0.40 \mathrm{mmol} / 1$ and $0.65 \mathrm{mmol} / 1$ repectively (Zeres et al., 1986; Sato et al., 1984 a,b). However, the $N$. crassa transport of L-arginine in mitochondria is passive, with a $\mathrm{K}_{\mathrm{m}}$ of $6.5 \mathrm{mmol} / \mathrm{l}$ ( $\mathrm{Yu}$ and Weiss, 1992).

L-Arginine hydrolysis is catalyzed by a restricted group of $\mathrm{Mn}^{2+}$ dependent enzymes, the arginases, which are widely spread in the biosphere. In mammals, two arginase isoenzymes, type I and type II, occur displaying similar physicochemical properties at different subcellular sites. Type I arginase is found at the hepatocytes cytosol, actively associated with the urea cycle. Type II arginase is a mitochondrial enzyme found in

\footnotetext{
${ }^{*}$ Author for correspondence
} 
extrahepatic tissues with very little or almost no meaning with respect to the liver metabolism (Jenkinson et al., 1996). The physiological meaning of type II arginase is not quite clear, probably being involved with the maintenance of L-arginine at intracellular levels in extrahepatic tissues for the control of polyamines, GABA, nitric oxide, proline and glutamate metabolism (Russel and McVicker 1972; Johnson and Roberts, 1984; Verma and Boutwell, 1981; Yip and Knox, 1972; Daghigh et al., 1994).

Normally, fish arginases are present in the mitochondrial fraction, except in dipnoic fishes (lungfish) that possess cytosolic arginase Mommsen and Walsh (1989). However, studies with Batrachoididae fish showed that arginase was equally distributed in both mitochondria and cytosolic fractions, amounting around fifty percent of activity in each compartment. Furthermore, both arginase fractions displayed identical physicochemical properties in ion exchange chromatography and in polyacrylamide gel electrophoresis (PAGE) without denaturation conditions and thus, corroborating the assumption that both were a single enzyme (Anderson and Walsh, 1995).

The low ureogenic potential of the enzymes present in the Krebs-Henseleit cycle has been established by studies with Antarctic fishes from McMurdo Bay (Raymond and DeVries, 1998) and from Admiralty Bay (Rodrigues et al., 2002). However, it has been found that the catalytic activitiy of L-arginase is far above the catalytic activity of the other enzymes of the KrebsHenseleit cycle. Furthermore, an interesting observation was that the catalytic activity concentration of hepatic arginase from Notothenia rossii was 10 times higher than that of Notothenia neglecta.

Thus, the main aim of the present work was to study the tissue metabolism of L-arginine in the Antarctic fish $N$. neglecta and $N$. rossii by analysing the levels of arginase and its kinetic properties in mitochondrial suspension and extract near fish physiological temperature, trying to understand the role of mitochondria membranes in the transport of L-arginine, as well as the subcellular site of the main enzymes of the KrebsHenseleit cycle.

\section{MATERIAL AND METHODS}

Mature Notothenia rossii and neglecta were captured near the Brazilian Antarctic Station Comandante Ferraz at Admiralty Bay, King George Island, South Shetlands, Antarctic. Fish weighting 310 to $450 \mathrm{~g}$ were maintained without foods at $0^{\circ} \mathrm{C}$ in an aquarium in a proportion of 1 fish/100 1 of sea water under constant aeration. The period of time between the capture of the fish and the sampling was 48 to $72 \mathrm{~h}$. Freshly excised tissues were homogenized in the proportion of $1 \mathrm{~g}$ for $10 \mathrm{ml}$ of a HEPES buffer 20mmol/1 $\mathrm{pH} 7.4$ containing trimethylamine $\mathrm{N}$-oxide $1 \mathrm{mmol} / \mathrm{l}$, $\mathrm{KH}_{2} \mathrm{PO}_{4}, 5 \mathrm{mmol} / 1$, EDTA $0.5 \mathrm{mmol} / 1$ and sucrose $250 \mathrm{mmol} / 1$ (compartmentalization buffer) as described by Polez et al. (1998).

The homogenates were spun down for $10 \mathrm{~min}$ at $1,500 \mathrm{xg}$ in a refrigerated centrifuge and the supernatants were used for enzymatic assay. For the preparation of the mitochondrial fraction, the supernatants were spun down $10 \mathrm{~min}$ at $14,000 \mathrm{xg}$ and the sediment was washed twice with the compartmentalization buffer. For the preparation of the mitochondrial extract, part of the mitochondrial sediment obtained as above was suspended in the same buffer without EDTA but with Triton X-100 $0.1 \%(\mathrm{v} / \mathrm{v})$, sonicated twice with $30 \mathrm{sec}$ strokes for the disruption of the mitochondria and then spun down $10 \mathrm{~min}$ at $14,000 \mathrm{xg}$ the supernatant was used for kinectic studies. All the kinectic studies were carried out at $0^{\circ} \mathrm{C}$.

The mitochondria integrity was evaluated by means of the assay of glutamate dehydrogenase (GDH). The cytosolic contamination of the mitochondrial fractions was evaluated by the assay of lactate dehydrogenase (LDH). The assays of LDH and GDH activities were carried out as described by Vorhaben and Campbell (1972) and Ciardello et al. (1997), respectively. The combined actvities of carbamoylphosphate synthetase I and III (CPS-I and CPS-III) were assayed in $1 \mathrm{ml}$ of the HEPES buffer $50 \mathrm{mmol} / 1$, pH 8.0 containing (mmol/l) ATP 20, glutamine 10, $\mathrm{NH}_{4} \mathrm{Cl} 100$, Lornithine 10, $\mathrm{NaHCO}_{3} \quad 10, \mathrm{MgSO}_{4} \quad 24, \mathrm{~N}-$ acetylglutamic acid (AGA) 5 and ornithine carbamoyl transferase (OTC) $1 \mathrm{U} / \mathrm{ml}$. The reaction was suspended by adding of $200 \mu \mathrm{l}$ of trichloroacetic acid (TCA, 70\% w/v) and the content of the tube were centrifuged for $10 \mathrm{~min}$ at $14,000 x g$ and the supernatant was used for 
citrulline determination according Bergmeyer (1983).

Ornithine carbamoyl transferase was analysed in $1 \mathrm{ml}$ triethanolamine (TEA, 200mmol/1, $\mathrm{pH} \mathrm{7.6),}$ L-ornithine and carbamoyl phosphate $5 \mathrm{mmol} / 1$ each. The reaction was stopped by the addition $500 \mu \mathrm{l}$ of $5 \mathrm{~mol} / \mathrm{l}$ perchloric acid and kept for 10 $\mathrm{min}$ in an ice bath and then spun down for $10 \mathrm{~min}$ at $14,000 \mathrm{xg}$. The citrulline formation was assayed according to Bergmayer (1983). Glutamine synthetase (GS) was analyzed in $1 \mathrm{ml}$ of TRISacetate buffer $(80 \mathrm{mmol} / 1, \mathrm{pH} 7.4)$, containing (mmol/l) hydroxylamine $40, \mathrm{MgSO}_{4} 20$, sodium glutamate 80 , ATP 10 , phosphoenolpyruvate 10 , pyruvate kinase $0.6 \mathrm{U}$ and $\beta$-mercaptoethanol $20 \mathrm{mmol} / \mathrm{l}$. The reaction was stopped adding $1,5 \mathrm{ml}$ of $0,37 \mathrm{M}$ ferric chloride in $0,67 \mathrm{M} \mathrm{HCl}$ and $0,2 \mathrm{M}$ trichloroacetic acid, and spun down for $10 \mathrm{~min}$ at $14,000 \times \mathrm{xg}$ to remove the denatured protein (Pamijans et al., 1962). The tissue level arginase activity was determined in glycine buffer (60mmol/l pH 9.5) containing (mmol/l) L-arginine 250 and $\mathrm{MnCl}_{2} 5$ and in TRIS-HCl (80 pH 7.4) containing L-arginine 250 and $\mathrm{MnCl}_{2} 5 \mathrm{mmol} / \mathrm{l}$ respesctivelv. The urea originated from this reaction was assayed by the method of Geyer and Dabich (1971).

All enzymes activities were expressed in International Units $(\mu \mathrm{mol} / \mathrm{min})$. The protein content was estimated by the method of Lowry et al. (1951).

\section{RESULTS AND DISCUSSION}

The relative distribution of arginase activity in $N$. neglecta tissues is shown in Fig. 1. The argininolytic activity in this Antarctic fish was high in the kidney's distal portion and liver than other tissues. Hunter (1929) reported that liver was the main organic territory for the genetic expression of arginase. Also, Campbell (1961) found that in Mustellus canis, arginase level was as high as 1.12 and $0.67 \mathrm{U} / \mathrm{mg}$ protein in the liver and kidney respectively, when kept under saturating conditions of substrate in $\mathrm{pH} 9.5$ and at $20^{\circ} \mathrm{C}$. Arginase activity values in $N$. neglecta's liver, whole kidney and its distal portion at $0^{\circ} \mathrm{C}$ in substrate saturation condition were $4.8 \pm 3.0$, $19.2 \pm 4.6$ and $39 \pm 26.0 \mathrm{mU} / \mathrm{mg}$ respectively. These assays were carrried out at a non-physiological $\mathrm{pH}$ 9.5 , resulting in an activity values 4 to 6 times higher than that found at $\mathrm{pH}$ 7.4. Felski et al. (1998) observed high levels of arginase in kidney than in liver of the different species of teleost fish.

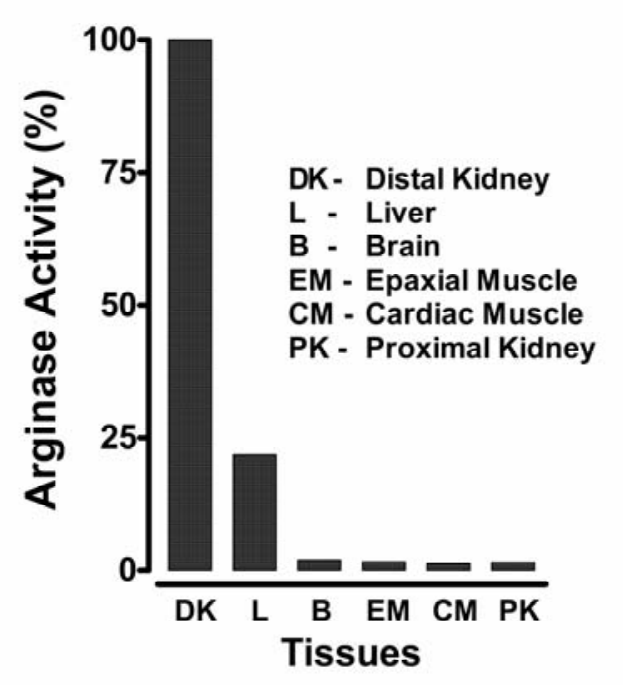

Figure 1 - Arginase specific activity percentual levels in $N$. neglecta tissues $(n=8)$. The activities were assayed in cell free homogenates after spinning down at 1,500xg. Reaction medium: glycine, 50mmol/1, pH 9.5, L-arginine 250mmol/1 and $\mathrm{MnCl}_{2} 5 \mathrm{mmol} / \mathrm{l}$. 
The activity of arginase found in the kidney of Cyprinus carpio was 4 times higher than that found in the liver while in the kidney of Carassius auratus, the activity of arginase was 50 times higher than that found in liver. In spite of the fact that the fish species studied by Felski et al. (1998) were neither ureotelic nor ureosmotic ones, they showed different levels of tissue arginase, a physiological condition that could be due to the maintenance of adequate levels of tissues Larginine.
Results regarding the subcellular distribution of liver enzymes from the urea and the glutamine metabolism in $N$. neglecta are shown in Fig. 2. Arginase and OTC showed to be the enzymes from the mitochondrial cell compartment, while GS and CPS were prevalent in the cytosol of hepatic cells. The specific activities of CPS, OTC and arginase at the mitosol of hepatic cells from $N$. neglecta and $N$. rossii are shown in Table 1.

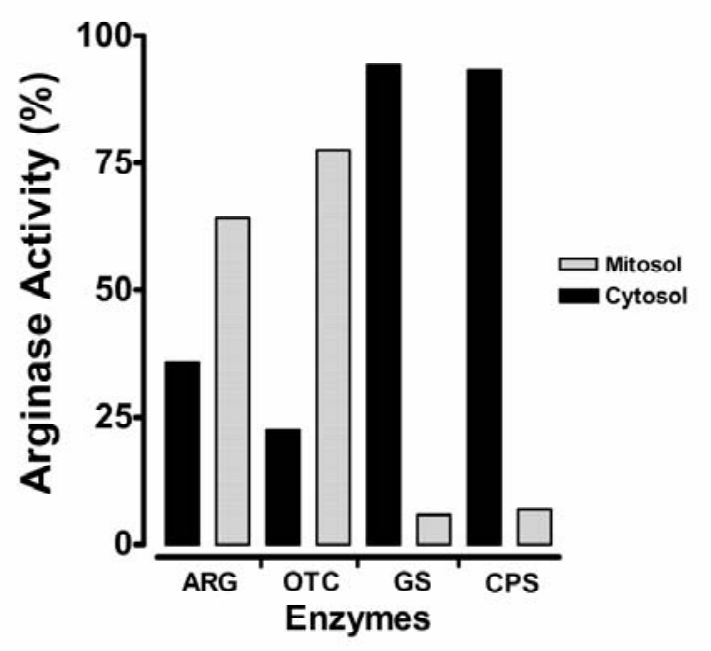

Figure 2 - Subcellular localization of enzymes from the urea and glutamine metabolisms in $N$. neglecta liver $(\mathrm{n}=8)$. Lactate dehydrogenase $(\mathrm{LDH})$ and glutamine dehydrogenase (GDH) were used as markers of the subcellular fractions. LDH activity was $98.8 \%$ at the cytosol and $1.2 \%$ at the mitosol and GDH was $76.7 \%$ at the mitosol and $23.3 \%$ at the cytosol. ARG, arginase; OTC, ornithine transcarbamoylase; GS, glutamine synthetase; CPS, carbamoylphosphate synthetase.

Along the evolution of vertebrates, both arginase and CPS-III were preserved at the liver mitochondrial fraction in teleost and elasmobranch fish. Conservation of CPS-III to CPS-I seemed to be happened during the step of evolution that was directed towards the origin of the lungfish, a dipnoic fish (Mommsen and Walsh, 1989). In view of the fact that a few species of fish with low capability for urea synthesis expressed mitochondrial GS, its presence in the mitochondrial fraction was of particular importance in ureosmotic fish displaying a functional urea cycle where glutamine acted as substrate for the CPS-III reaction.

Table 1 - Specific activity of arginase, ornithine transcarbamoilase (OTC) and carbamoylphosphate synthetase (CPS) in mitochondrial extracts from the liver of Antarctic fish N. neglecta $(\mathrm{n}=8)$ and $N$. rossii $(\mathrm{n}=7)$. The activities were assayed at $\mathrm{pH} 7.4$ and at $0^{\circ} \mathrm{C}$.

\begin{tabular}{l|c|c}
\hline \multirow{2}{*}{ Enzymes } & \multicolumn{2}{|c}{ Specific Activity \pm SD (mU/mg protein) } \\
\cline { 2 - 3 } & N. neglecta & N. rossii \\
\hline Arginase & $19.46 \pm 10.12$ & $89.20 \pm 45.28$ \\
OTC & $0.10 \pm 0.044$ & $0.90 \pm 0.43$ \\
CPS & $0.017 \pm 0.006$ & $0.021 \pm 0.002$ \\
\hline
\end{tabular}




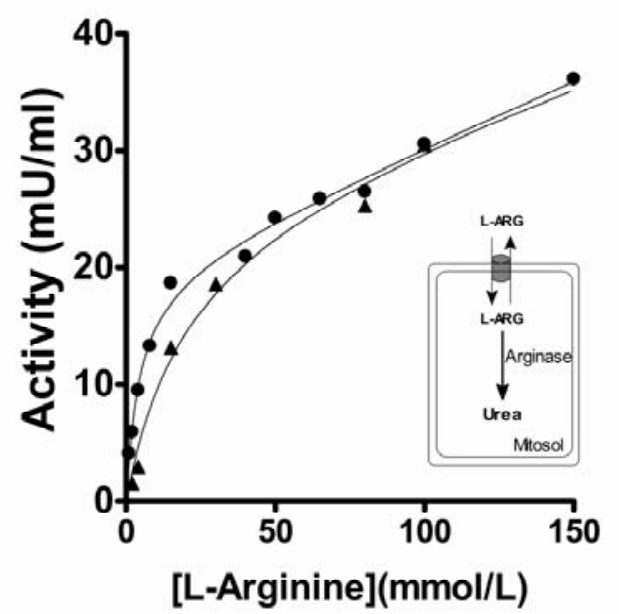

Figure 3 - Kinetic parameters involving the effect of L-arginine on the argininolytic activity. Aliquot of N. neglecta liver mitochondrial extracts (- - -) and suspension (- - -) were incubated in compartmentalization buffer without EDTA, $\mathrm{pH} 7.4$ containing $\mathrm{MnCl}_{2}$ $0.5 \mathrm{mmol} / \mathrm{l}$. The reactions were carried out at a temperature of $0^{\circ} \mathrm{C}$.

The low specific activity of CPS and OTC enzymes in Antarctic fish from McMurdo Bay $(D$. mawsoni, $G$. acuticeps, $N$. angustata, $L$. dearborni) studied by Raymond and DeVries (1998) as well as the the values shown in Table 1 for fish from Admiralty Bay - King George Island, are the characteristics of fish displaying low ureogenic capacity.

Nevertheless, very near in the phylogenetic range, $N$. rossii displayed 5 and 9 times higher levels of OTC and arginase respectively than that found in $N$. neglecta, a fact regarded as the metabolic needs congenital to the feeding behavior of these species. Considering the central role displayed by arginase in maintaining adequate levels of L-arginine in tissues and biological fluids, these experiments were conducted at $\mathrm{pH}$ and temperature near the fish physiological condition. On the other hand, the subcellular sites of arginases from Antarctic fish, as well as the hepatic tissue argininolytic activity encompass also L-arginine transportation through the mitochondrial membrane. Furthermore, the subcellular compartmentalization of arginase and the disponibility of $\mathrm{Mn}^{2+}$ in the mitochondrial spaces may represent an important site for the metabolic control of L-arginine.

The $\mathrm{L}$-arginine $\mathrm{K}_{\text {mapp }}$ values assayed with suspensions of liver mitochondria from $N$. neglecta and $N$. rossii were $8.42 \pm 3.95$ and $9.16 \pm 0.94 \mathrm{mmol} / \mathrm{l}$, while the $\mathrm{K}_{\mathrm{m}}$ values assayed with mitochondria extracts were $2.40 \pm 0.55$ and
$4.46 \pm 0.53 \mathrm{mmol} / \mathrm{l}$, respectively (Fig. 3). Arginases from teleost fish displayed $\mathrm{K}_{\mathrm{m}}$ values for $\mathrm{L}$ arginine around $11.6 \mathrm{mmol} / \mathrm{l}$ at $\mathrm{pH} 9.5$, while arginases from elasmobranch fish displayed $\mathrm{K}_{\mathrm{m}}$ values of $1.2 \mathrm{mmol} / \mathrm{l}$ at $\mathrm{pH} 9.8$ (Jenkinson et al., 1996). Considering that the optimum $\mathrm{pH}$ for arginases was around 9.5, most of the kinetic data so far obtained were carried out in reaction media with $\mathrm{pH}$ values away from the physiological band of living organisms (Campbell, 1961; Kadowaki and Nesheim, 1979; Reczkowski and Ash, 1994; Jenkinson et al., 1996).

Another important aspect to be considered is in regard to the subcellular site of arginases and their distribution along the phylogenetic rank. In this sense, the determination of the kinetic constants of mitochondria arginase in tissue homogenates may be a most valuable source of information in regard to the transport mechanism of L-arginine through the mitochondrial membrane. Experiments with liver homogenates from the elasmobranch Mustelus canis showed $\mathrm{K}_{\mathrm{m}}=8.11 \mathrm{mmol} / 1$ in a medium containing glycine at $\mathrm{pH} 9.5$, which was far above the values described so far for elasmobranches (Campbell, 1961).

Carvajal et al. (1987) found values of $\mathrm{K}_{\mathrm{m}}$ of $9.1 \mathrm{mmol} / 1$ at $\mathrm{pH} 7.6$ and $22.5 \mathrm{mmol} / \mathrm{l}$ at $\mathrm{pH} 9.6$ at $37^{\circ} \mathrm{C}$ in a partially purified liver arginase preparation from the teleost fish Genypterus maculatus. In liver arginase preparation from Merlucius gayl, Carvajal et al. (1989) found $\mathrm{K}_{\mathrm{m}}$ 
values of 1.7 and $10.3 \mathrm{mmol} / \mathrm{l}$ at $\mathrm{pH} 9.5$ and 7.5 , respectively without alterations at the temperatures between 9 and $37^{\circ} \mathrm{C}$. They also pointed out that site of arginase in the mitochondria matrix and their respective kinetic properties might avoid the indiscriminate hydrolysis of arginine and controled the use of this aminoacid as a source of energy at the M. gayl liver.

Comparing the kinetic data of arginases from $N$. neglecta and $N$. rossii, was $\mathrm{K}_{\text {mapp }} 3.6$ and 2.0 times higher than that of the $\mathrm{K}_{\mathrm{m}}$ values, respectively. The differences between $K_{m}$ and $K_{\text {mapp }}$ determinations take place in the access of arginine towards the argininolytic system, that is, the $\mathrm{K}_{\text {mapp }}$ at the mitochondrial membrane may play an important physiological role in the control of arginine levels in cell.

In order to elucidade the role of the mitochondrial membrane in the arginolytic process, an experiment was carried out to establish the aproximate time of L-arginine transport across the mitochondrial membrane (Fig. 4). The time of arginine transport towards the mitochondrial spaces limited the arginase substrate disposability and the consequent urea synthesis, as shown in Fig. 4. Urea formation was linear in the system containing mitochondria extract, while in the system containing mitochondrial suspension, it became linear only 20 minutes after the begining of the experiment.

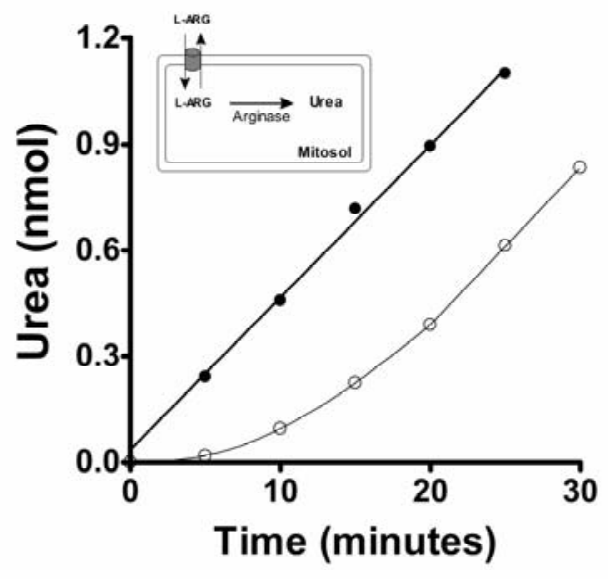

Figure 4 - Time course of L-arginine transport. Samples of $N$. neglecta liver mitochondrial

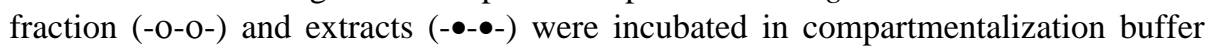
without EDTA, $\mathrm{pH} 7.4$, containing L-arginine $100 \mathrm{mmol} / \mathrm{l}$ and $\mathrm{MnCl}_{2} 5 \mathrm{mmol} / \mathrm{l}$. The reactions were carried out at a temperature of $0^{\circ} \mathrm{C}$ near fish physiological conditions.

Results showed that the arginine metabolism in mitochondrial suspensions involved also the arginine transport through the mitochondrial membrane, a process that reached an equilibrium establishing a stationary state of L-arginine concentration between both the outer and inner mitochondrial compartments. Thus, the differences found in the kinetic behavior of the preparations in Fig. 4 suggested that the mitochondrial membranes displayed a fundamental role in the L-arginine access towards the inner mitochondrial spaces. This observation was supported by the 2.0 to 3.6 difference found between the $\mathrm{K}_{\text {mapp }}$ established for the mitochondrial suspension and the $\mathrm{K}_{\mathrm{m}}$ found for the mitochondrial extracts, suggesting that the mitochondrial membranes displayed an important role in the access of L-arginine towards the intramitochondrial spaces.

Studies by Rodrigues et al. (2004) on the comparative aspects of L-arginine metabolism carried out with the Antarctic fishes N. neglecta and $N$. rossii, and the tropical fish grouper (Epinephelus marginatus) showed that arginase $\mathrm{K}_{\mathrm{m}}$ assayed in both mitochondrial suspensions and mitochondrial extracts gave lower values in tropical fishes preparations than the ones found in the Antarctic ones. The effect of manganes ion on the activity of the argininolytic system in Antarctic fish ( $N$. neglecta and $N$. rossii) was evaluated in mitochondrial suspension and extacts (Fig. 5). It is known that the catalytic activity of arginases from different species depends on the presence of a divalent ion, especially $\mathrm{Mn}^{2+}$ that acts as an 
activator and stabilizer of the enzyme structure (Kuhn, 1991). In the cytosolic fraction of rat liver, Maggini et al. (1992) described the presence of arginase with two sites for $\mathrm{Mn}^{2+}$. It was postulated that arginine and $\mathrm{Mn}^{2+}$ in concentrations near the physiological ones could control ureogenesis in vivo.

In arginine concentrations near the saturation level and at $\mathrm{pH}$ and temperature near the physiological condition, the argininolytic systems present in mitochondrial suspensions and extracts from the liver of $N$. neglecta and $N$. rossii were activated by $\mathrm{Mn}^{2+}$ below the $500 \mu \mathrm{mol} / \mathrm{l}$. However, $\mathrm{Mn}^{2+}$ above

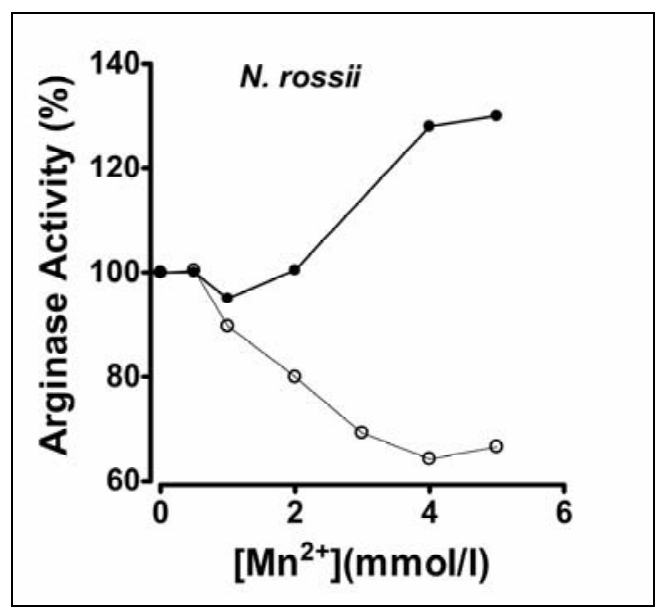

the $500 \mu \mathrm{mol} / \mathrm{l}$, the argininolytic system present in mitochondrial extracts was inhibited while the system containing mitochondria was activated. This showed the role of the mitochondria membranes in the control of argininolytic activity in the liver of Antarctic fish. Studies on the mechanism of action of $\mathrm{Mn}^{2+}$ on the arginase activity as well as maintainance of the protein structure and the argininolytic process, have contributed for the understanding of L-arginine metabolism cell and tissues (Reczkowski and Ash, 1994; Green, et al., 1991; Maggini et al., 1992).

Figure 5 - The effect of the $\mathrm{Mn}^{2+}$ ion on the argininolytic activity. Samples of liver mitochondrial

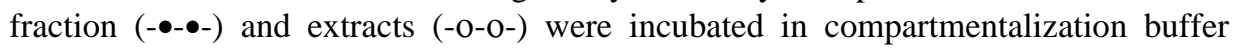
without EDTA, pH 7.4, containing L-arginine $15 \mathrm{mmol} / \mathrm{l}$. The reactions were carried out at the temperature of $0^{\circ} \mathrm{C}$.

Most of these kinectic studies were carried out with arginases purified from different species and the experiments were not carried out always near the physiological conditions. On the other hand, the subcellular distribution of enzymes in the nitrogen metabolism, in especially arginase, has labeled the evolution of living beings as a reflex of a probable strategy of metabolic adaptation. In this sense, the mitochondrial localization of arginases deserve a special attention with regard to the possible role of mitochondrial membranes in the control of argininolytic process and to the tissue needs of this amino acid towards protein synthesis and of other nitrogen compounds. Present results showed the importance of the mitochondrial membranes in $N$. neglecta and $N$. rossii hepatic arginolysis control near the physiological conditions.

\section{REFERENCES}

Aderson, P. M. and Walsh, P. J. J. (1995), Subcellular localization and biochemical properties of the enzymes of carbamoyl phosphate synthetase and urea synthesis in the batrachoidid fishes Osanus beta, Opsanus tau and Porichthys notatus. J. Exp. Biol., 198,755-766.

Bergmeyer, H. U. (1983), Methods of enzymatic analysis. $3^{\text {rd }}$ ed. Florida: VCH Publ. v. 3. pp. 319-333.

Campbell, J. W. (1961), Studies on tissue arginase and ureogenesis in the elasmobranch, Mustelus canis. Arch. Biochem. Biophy., 93, 448-455.

Carvajal, N.; Kessi, E. and Ainol, L. (1987), Subcellular localization and kinetic properties of arginase from the liver of Genypterus maculatus. Comp. Biochem. Physiol., 88B: (1), 229-231. 
Carvajal, N.; Kessi, E. and Jeres, D. (1989), Studies of the control of arginine hydrolysis in the liver of Merlucius gayl. Comp. Biochem. Physiol., 94B: (1), 195-199.

Ciardiello, M. A.; Camardella, L.; Carratore, V. and Prisco, G. (1997), Enzymes in Antarctic fish: glucose-6-phosphate dehydrogenase and glutamate dehydrogenase. Comp. Biochem. Physiol., 118A: (4), 1031-1036.

Daghigh, F.; Fukuto, J. M. and Ash, D. E. (1994), Inhibition of rat liver arginase by an intermediate in NO biosynthesis, NG-hydroxy-L-arginine: Implications for the regulation of nitric oxide biosynthesis by arginase. Biochem. Biophys. Res. Commun., 202, 174-180.

Felskie, A. K.; Anderson, P. M. and Wright, P. A. (1998), Expression and activity of carbamoyl phosphate synthetase III and ornithine urea cycle enzymes in various tissues of four fish species. Comp. Biochem. Physiol., 119B: (2), 355-364.

Geyer, J. W. and Dabich, D. (1971), Rapid method for the determination of arginase activity in tissue homogenate. Anal. Biochem., 39, 412-417.

Green, S. M.; Ginsburg, A.; Lewis, M. S. and Hensley, P. (1991), Roles of metal ions in the maintenance of the tertiary and quaternary structure of arginase from Saccharomyces cerevisiae. J. Biol. Chem., 266: (32), 21474-21481.

Hird,F. J. R. (1986), The importance of arginine in evolution. Comp. Biochem. Physiol., 85B: (2), 285288.

Hunter, A. (1929), Further observations on the distribution of arginase in fishes. J. Biol. Chem., 81, 505-509.

Jenkinson, C.; Grody, W. W. and Cederbaum, S. D. (1996), Comparative properties of arginases. Comp. Biochem. Physiol., 114B: (1), 107-132.

Johnson, J. L. and Roberts, E. (1984), Arginine metabolism in mouse brain synaptosomes. $J$. Neurochem., 42, 1123-1126.

Kadowaki, H. and Nesheim, M. C. (1979), Purification and properties of chick kidney arginase. Int. J. Biochem., 10, 303-310.

Kuhn, N. J.; Talbot, J. and Simon, W. (1991), pHSensitive control of arginase by $\mathrm{Mn}(\mathrm{II})$ ions at submicromolar concentrations. Arch. Biochem. Biophy., 286: (1), 217-221.

Lowry, O. H.; Rosenbrough, N. J. Farr, A. C. and Randall, R. J. (1951), Protein measurement with the Folin fenol reagent. J. Biol. Chem., 193, 265-275.

Maggini, S.; Stoecklin-Tschan, F. B.; Mörikofer-Zwez, S. and Walter, P. (1992), New kinetic parameters for rat liver arginase measured at near-physiological steady-state concentrations of arginine and $\mathrm{Mn}^{2+}$. Biochem. J., 283, 653-653.

Mommsen, T. P. and Walsh, P. J. (1989), Evolution of urea synthesis in vertebrates: The Piscine Connection. Science, 243, 72-74.
Pamiljans, V.; Krishnaswamy, P. R.; Dumville, G. and Meister, A. (1962), Studies on the mechanism of glutamine synthesis, isolation and properties of the enzyme from sheep brain. Biochem., 1: (1), 153-158.

Polez, V. L. P.; Monzani, P. S. and Morais, G. (1998), The urea cycle enzymes glutamine synthetase, carbamoylphosphate synthetase and arginase from the freshwater teleost fish Hoplerythrinus unitaeniatus, Hoplias malabaricus and Hoplias lacerdae: comparison and enzyme compartimentalization. $J$. Comp. Biol., 3: (2), 185-190.

Raymond, J. A. and DeVries, A. L. (1998), Elevated concentrations and synthetic pathways of trimethylamine oxide and urea in some teleost fishes of MacMurdo Sound, Antarctica. Fish Physiol. Biochem., 18, 387-398.

Reczkowski, R. S. and Ash, D. E. (1994), Rat liver arginase: kinetic mechanism, alternate substrates, and inhibitors. Arch. Biochem. Biophys., 312: (1), 31-37.

Rodrigues, E.; Ribeiro, A. C. M. T. and Bacila, M. (2002), Localização subcelular de enzimas do ciclo da uréia e do metabolismo da glutamina em fígado de peixes antárticos. In: Seminário sobre Pesquisas Antárticas, 10., São Paulo. Anais ... São Paulo: Instituto de Geociências, USP. pp. 59.

Rodrigues, E.; Ribeiro, A. C. M. T.; Silva, M. S. M. and Bacila, M. (2004), Comparative aspects of LArginine metabolism in Antarctic and Tropical fishes. In: SCAR, 28.; COMNAP, 16., 2004, Bremem. Meeting... Bremem, DE: Congress Centre. pp. 122.

Russel, D. H. and McVicker, T. A. (1972), Poliamine biogenesis in the rat mammary gland during pregnancy and lactation. Biochem. J., 130, 71-76.

Sato, T.; Ohsumi, Y. and Anraku, Y. (1984a), Substrate specificities of active transport systems for amino acids in vacuolar-membrane vesicles of Saccharomyces cerevisiae - Evidence of seven independent proton/amino acid antiport systems. $J$. Biol. Chem., 259: (18), 11505-11508.

Sato, T.; Ohsumi, Y. and Anraku, Y. (1984b), An arginine/histidine exchange transport system in vacuolar-membrane vesicles of Saccharomyces cerevisiae. J. Biol. Chem., 259: (18), 11509-11511.

Verma, A. K. and Boutwell, R. K. (1981), Characterization of arginase activity from mouse epidermis and its relation to ornithine decarboxylase induction by the tumor-promoting agent, 12-Otetradecanoylphorbol-13-acetate. Biochim. Biophys. Acta., 677, 184-189.

Vorhaben, J. E. and Campbell, J. W. (1972), Glutamine synthetase: a mitochondrial enzyme in uricotelic species. J. Biol. Chem., 247: (9), 2763-2767.

$\mathrm{Wu}, \mathrm{G}$. and Morris Jr., M. (1998), Arginine metabolism: nitric oxide and beyond. Biochem. J., 336, 1-17.

Yip, M. C. M. and Knox, W. E. (1972), Function of arginase in lactating mammary gland. Biochem. J., 127, 893-899. 
Yu, Y. G. and Weiss, R. L. (1992), Arginine transport in mitochondria of Neurospora crassa. J. Biol. Chem., 267: (22), 15491-15495.

Zeres, C. R.; Weiss, R. L.; Franklin, C. and Bowman, B. J. (1986), The properties of arginine transport in vacuolar membrane vesicles of Neurospora crassa. J. Biol. Chem., 261: (19), 8877-8882.

Received: December 17, 2004; Revised: October 06, 2005; Accepted: April 04, 2006. 